УДК 347.9, ББК 67.310, ГРНТИ 10.31.01 , КОД ВАК 12.00.15

И. В. Рехтина, М. А. Боловнев

Барнаул, Россия

\title{
ИСПОЛЬЗОВАНИЕ В ПОНЯТИЙНОМ АППАРАТЕ ГРАЖДАНСКОГО И АРБИТРАЖНОГО ПРОЦЕССУАЛЬНОГО ПРАВА ТЕРМИНОВ ИНОСТРАННОГО ПРОИСХОЖДЕНИЯ
}

Предлагаемая статья посвящена анализу терминов иностранного происхождения, которые активно используются в юридчческой сфере, в большей степени в понятийном аппарате гражданского и арбитражного прочессов, как в научном обороте и доктрине, путем включения в статьи, монографии, научно-практические издания, так $и$ в официальной судебной практике при фиксации в различного рода судебных актах: определениях, решениях, постановлениях, судебных приказах. Авторы излагают общие подходы и положения относительно правил и требований юридической техники, при этом уделяют особое внимание юридической терминологии, ее понятию, значению, условиям использования и видам юридических терминов. В статье описьваются два способа образования данных терминов в русском юридическом языке, указываются их подвиды, приводятся примеры заимствованных иностранных терминов и категорий. В завершении статьи авторы обозначают как положительные, так и отрицательные моменть при заимствовании и рецепщии правовых терминов иностранного происхождения.

Ключевые слова: гражданский проиесс, арбитражный проиесс, понятийный аппарат, иностранные термины, рецепция.

Сведения об авторе: Ирина Владимировна Рехтина, кандидат юридических наук, доцент кафедры трудового, экологического права и гражданского прочесса Алтайского государственного университета.656049, Барнаул, пр. Ленина, 61.E-mail: jerdel80@mail.ru.

Сведения об авторе: Михаил Алексеевич Боловнев, преподаватель кафедры трудового, экологического права и гражданского прочесса Алтайского государственного университета.656049, Барнаул, пр. Ленина, 61.E-mail: slovak92@mail.ru.

I. V. Rekhtina, M. A. Bolovnev

Barnaul, Russia

TERMS OF FOREIGN ORIGIN IN CONCEPTUAL FRAMEWORK OF CIVIL LAW AND LAW OF ARBITRAL PROCEDURE

The proposed article is devoted to the analysis of terms of foreign origin, which are actively used in the legal sphere, mostly in the conceptual framework of civil and arbitral procedures, both 
in scientific circulation and doctrine, by including into articles, monographs, scientific and generalaudience publications, and in the official judicial practice when recording various kinds of judicial acts: definitions, decisions, rulings, judicial orders. The authors state common approaches and provisions regarding the rules and requirements of legal writing, upon that paying special attention to legal terminology, its concept, meaning, limits of use and types of legal terms. The article describes two ways of forming these terms in the Russian legal language, their subspecies are indicated, examples of borrowed foreign terms and categories are given. At the end of the article, the authors refer to both positive and negative points when borrowing and adopting legal terms of foreign origin.

Key words: civil procedure, arbitral procedure, conceptual framework, foreign terms, adoption.

About the author: Rekhtina Irina Vladimirovna, Candidate of Juridical Sciences, Associate Professor of the Chair of Labor, Environmental Law and Civil Process, Department of Law, Altai State University, prospect Lenina, d.61, Barnaul,656049.E-mail: jerdel80@mail.ru.

About the author: Bolovnev Mikhail Aleskseevich, Lecturer of the Chair of Labor, Environmental Law and Civil Process, Department of Law, Altai State University, prospekt Lenina, d.61, Barnaul, 656049.E-mail: slovak92@mail.ru.

У каждой профессии есть своя, присущая только ей терминология, специфический или профессиональный лексикон. Представители одной профессии могут разговаривать между собой так, что остальные люди их просто не поймут. Данная особенность общения присуща, как правило, врачам, учителям, журналистам и, конечно, юристам. Залогом качества юридического языка является соблюдение правил юридической техники.

Юридическая техника - это система средств, правил и приемов подготовки и упорядочения правовых актов, применяемая в целях обеспечения их совершенства и повышения эффективности [Лызлов 2009: 12].

Основным объектом юридической техники является текст правовых актов, информационное воплощение юридических предписаний. При их принятии важно учитывать, чтобы содержание таких предписаний (дух) и форма (буква) соответствовали друг другу, чтобы исключались неясности и двусмысленности. 
Юридическая техника призвана структурировать правовой материал, совершенствовать язык правовых актов, делать его более понятным, точным и грамотным. Во многом именно уровень юридической техники символизирует собой определенный уровень правовой культуры конкретного общества.

Техническими средствами являются юридические термины (словесное выражение понятий, используемых при изложении содержания правового акта) и юридические конструкции (специфическое строение нормативного материала, складывающееся из определенного сочетания субъективных прав, льгот, поощрений, обязанностей, запретов, приостановлений, наказаний и т.п.). В качестве юридических конструкций выступают те или иные правовые режимы, юридический состав правонарушения и т. п. [Матузов 2004: 92].

Язык права - важнейший элемент юридической техники, поскольку он связан непосредственно с выражением права.

Язык и право являются социальными нормативными иерархизированными системами (наличия определенных моделей во взаимосвязях одних элементов другим), регулирующими поведение людей, причем уникальной особенностью языка как системы является его знаковость, а права - государственно-властный характер. Общими для языка и права как социальных феноменов являются свойства системности, нормативности и иерархичности.

В сфере юридической деятельности, особенно в сфере правотворчества, немаловажную роль играет терминология. От точности употребления терминов в законе во многом зависит точность выражения воли законодателя, a, следовательно, и результативность закона и его значимость в жизни общества. Язык права в своем терминологическом выражении един и неразделим [Лызлов 2009: 43].

Юридическая терминология - выраженное непосредственно в тексте акта словесное обозначение определенного понятия. Относясь к средствам словесно-документального изложения, термины вместе с тем служат исходным материалом для строительства норм, их общностей. 
Таким образом, юридическая терминология имеет общее, сквозное значение в юридической технике, выступает в качестве начального звена при юридическом выражении воли законодателя [Алексеев 1981: 273].

Терминология характеризует особенность законодательного стиля. Как отмечал Рудольф Иеринг, благодаря юридической терминологии создается экономия сотни слов [Иеринг 2008: 62]. Терминологическая развитость законодательства свидетельствует об уровне культуры законотворчества. Чем богаче терминологический фонд, подробнее отработана и шире используется законодательная терминология, тем в большей мере достигается устойчивость, эффективность и лаконичность закона.

Юридическая терминология - основной и наиболее информативный пласт законодательства. Занимая в законах относительно небольшой объем нормативного текста, юридическая терминология отражает их основной смысл.

Насыщенность законодательного произведения терминологией значительной мере определяется профессионализмом разработчиков законопроекта: количество терминов, их сочетание друг с другом может быть самым различным, что зависит от темы, идеи законодательного текста (произведения), культуры законодателя. Распространенность терминологии в законодательном языке, его, так сказать, терминированность, в решающей мере обусловлена свойствами права. Норма права, как известно, представляет собой обобщение, типизацию определенных жизненных ситуаций, что находит выражение в словах-терминах [Элементарные начала 2003: 144].

При формулировании юридических норм используются три вида терминов: общеупотребляемые, специальные технические и специальные юридические.

К юридической технике принадлежит специальная юридическая терминология. Здесь термины - это обозначение юридических понятий, выражающих природу норм, юридические конструкции, отраслевую типизацию норм, то есть иных средств техники, относящихся к более глубоким пластам юридической материи, к содержанию права. Поэтому специальные 
юридические термины имеют свой, особый смысл. И, следовательно, юридические термины являются как бы мостиком от непосредственно воспринимаемых элементов текста ко всему комплексу технико-юридического инструментария.

Необходимыми условиями рационального использования терминологии являются:

a) единство терминологии. Одинаковые термины, используемые при формулировании юридических норм, должны иметь тождественное значение; недопустимо для обозначения одних и тех же понятий использовать разные термины;

б) общепризнанность терминологии. Используемые термины должны получить признание в науке и практике;

в) устойчивость терминологии. Недопустимо без особо веских причин отказываться от ранее используемой терминологии, вводить наряду с принятыми другие, по мнению некоторых авторов, более «удачные» термины [Алексеев 1981: 274].

Понятно, что чем больше в законодательном тексте терминов, тем более он точен, четок, лаконичен. Справедливо пишет В. М. Коган, что «употребление в законе исключительно терминов - это идеал, к которому право стремится и которого оно никогда не достигает из-за сложности самой действительности, составляющей предмет права и его цель» [Коган 1966: 36].

Нерасторжимая связь юридических понятий и соответствующих им терминов проявляется в том, что упорядочение правовой терминологии невозможно без достаточно глубокой научной разработки юридических понятий, их логического анализа и точного определения. Если юридические понятия определены недостаточно ясно, о точной, совершенной терминологии не может быть и речи. Как отмечал академик В. В. Виноградов, всякие «попытки упорядочения терминов без предварительного анализа понятий, которые ими выражаются, остаются безрезультатными» [Милославская 1999: $28]$. 
Проведя анализ гражданских процессуальных терминов, можно прийти к выводу, что они имеют различное происхождение. Некоторые из них имеют корни, уходящие в естественные науки, а некоторые появились путем заимствования из иностранных языков. Если использование в праве естественнонаучных терминов глубоко анализировалось и исследовалось учеными, то вопрос о терминах иностранного происхождения не является достаточно разработанным ни в теории права, ни в теории гражданского процесса.

В настоящее время юриспруденция пестрит иноязычной терминологией. Заимствование происходит из различных языков, но бесспорное лидерство принадлежит латинскому языку. Большинство терминов мы переняли именно из него, как, впрочем, и большинство других государств. Также российская юридическая наука часто обращается к английскому языку, есть и примеры заимствования из французского, немецкого, итальянского и других языков. Среди заимствованных терминов присутствуют как новые для нас слова, такие как медиаџия, транспарентность, преюдиџия, так и те, которые укоренились в профессиональном языке настолько, что некоторые наверняка и не предполагают, что они имеют иностранное происхождение, например, протест, договор, процедура.

Проведя анализ существующих терминов иностранного происхождения, можно сделать вывод, что существует два способа образования или появления данных понятий в юридической речи. Первый способ заключается в том, что за основу берется иностранный термин, а в русском языке используется его перевод. Примером первого способа образования слова может служить термин «брачный договор». Он перешел к нам из законодательства Англии и Франции, где существование брачного договора или marriage contract (англ.) либо contract de marriage (фр.) имеет очень давнюю историю. Так же при помощи первого способа к нам перешли такие термины как «жалоба» (от англ. appeal), «ущерб» (от лат. damnum; detrimentum; dispendium и англ. damage, injury). 
Второй способ представляет собой фактический переход иностранного слова в русский лексикон, когда иноязычный термин употребляется в несколько адаптированной для русского языка форме. Например, «апелляция» (от лат. appellatio - обращение); «казус» (от лат. casus - случай); «кодекс» (от лат. codex - собрание законов); «протест» (от лат. protestor - публично доказываю); «реституция» (от лат. restitutio - восстановление); «фальсификация» (от лат. falcificare - подделывать); «юстиция» (от лат. justitia - справедливость); «штраф» (от нем. strafe - наказание); «медиация» (от лат. mediare - посредничество); «преюдиция» (от лат. praejudicialis - относящийся к предыдущему судебному решению).

Несмотря на кажущуюся простоту второго способа формирования юридических терминов, он имеет свои особенности, которые позволяют выделить во втором способе два подвида, отличающиеся между собой по форме образования. Первый - это слова с простой формой образования. Примером здесь служат вышеуказанные термины: «апелляция», «медиация», «преюдиция» и т. д.

Второй подвид включает в себя термины, которые имеют сложную форму образования. Например, термин «акт» имеет два происхождения в зависимости от значения, которое мы ему придаем, от лат. actus - действие и actum документ. Термин «компетенция» появился в русском языке от лат. competentio. Однако слово «competentio» является производным от слова competo - добиваюсь, соответствую, подхожу. Термин «протокол» перешел к нам из французского языка от слова protocole. Но если обратиться к источникам французского термина protocole, то мы обнаружим, что во Францию этот термин пришел из Греции, где protokollon означает «первый лист манускрипта». Термин «процедура» мы переняли из французского языка от слова procedure, в то время как само слово procedure произошло от лат. ргосеdo - продвигаюсь.

Термин «юрисдикция» появился у нас от лат. jurisdictio судопроизводство, но само слово јurisdictio было образовано путем сложения 
слов jus, которое означат «право» и dico, которое переводится как «говорю». Термин «транспарентность» произошел от английского слова transparent, которое в свое время было воспринято из латинского языка путем слияния слов trans - «прозрачный, насквозь» и pareo - «быть очевидным», и приобрел значение «прозрачность, понятность, честность».

Из всего вышесказанного вытекает, что значительное количество юридических терминов, которые мы употребляем в гражданском и арбитражном процессах, являются заимствованными из иностранных языков. С одной стороны, это положительно сказывается на терминологии, поскольку одновременно происходит экономия средств юридической техники и заполняются пробелы, существующие в национальной процессуальной терминологии. Например, одно слово «преюдиция» заменяет такую, довольно громоздкую, конструкцию, как «обязательность для всех судов, рассматривающих дело, принять без проверки и доказательств факты, ранее установленные вступившим в законную силу судебным решением по другому делу», которой нет эквивалента в русском языке.

С другой стороны, в этом кроется практическая проблема, состоящая в том, что юридическая профессия подразумевает работу с людьми, не имеющими специального юридического образования, для которых восприятие подобных терминов представляется затруднительным. В связи с этим при заимствовании, рецепировании иностранных терминов и категорий и внедрении их в национальный юридический словооборот следует соблюдать разумный баланс между интересами профессионального юридического сообщества, отдельных граждан и общества в целом.

\section{ЛИТЕРАТУРА}

1. Алексеев С. С. Общая теория права: В 2-х тт. М., 1981. Т. 2.

2. Иеринг Р. Юридическая техника. М., 2008.

3. Коган В. М. Логико-юридическая структура советского уголовного закона. АлмаАта, 1966.

4. Льъзлов Д. Н., Картухин В. Ю. Юридическая техника. М., 2009. 
5. Матузов Н. И. Теория государства и права. М., 2004.

6. Милославская Д. Юридические термины и их интерпретации. Ростовская электронная газета. 1999. № 21.

7. Элементарные начала общей теории права. М., 2003.

\section{REFERENCES}

1. Alekseev S. S. General theory of law: In 2 vol. [Obshhaja teorija prava]. Moscow, 1981. Vol. 2.

2. Iering R. Legal Writing [Juridicheskaja tehnika]. Moscow, 2008.

3. Kogan V. M. Logical and Legal Structure of the Soviet Criminal Law [Logikojuridicheskaja struktura sovetskogo ugolovnogo zakona]. Alma-Ata, 1966.

4. Lyzlov D. N., Kartukhin V. Yu. Legal Writing [Juridicheskaja tehnika]. Moscow, 2009.

5. Matuzov N. I. Theory of State and Law [Teorija gosudarstva i prava]. Moscow, 2004.

6. Miloslavskaya D. Legal terms and their interpretations [Juridicheskie terminy $\mathrm{i}$ ih interpretacii]. Rostov electronic newspaper. 1999. № 21.

7. Basics of the general theory of law: Textbook for colleges [Jelementarnye nachala obshhej teorii prava]. Moscow, 2003. 